\title{
Body Interaction and Semiotic Approach in Volleyball School Education: Case of Tunisia
}

\author{
Neila Ghannouchi ${ }^{1,2}$, Hanene Lengliz ${ }^{2,3}$, Ali Elloumi ${ }^{4}$, Éric Dugas ${ }^{5}$ \\ ${ }^{1}$ Clinical Psychology: Intersubjectivity and Culture Laboratory, Tunis, Tunisia \\ ${ }^{2}$ University of Jendouba, Jendouba, Tunisia \\ ${ }^{3}$ UMR-EFFETS Laboratory, University of Toulouse-Jean Jaurès, Toulouse, France \\ ${ }^{4}$ TEC Laboratory, University of Paris Descartes, Paris, France \\ ${ }^{5}$ LACES EA 7437 Laboratory, University of Bordeaux, Bordeaux, France \\ Email: neilaghannouchi@gmail.com
}

How to cite this paper: Ghannouchi, N., Lengliz, H., Elloumi, A., \& Dugas, É. (2019). Body Interaction and Semiotic Approach in Volleyball School Education: Case of Tunisia. Advances in Applied Sociology, 9, 407-420.

https://doi.org/10.4236/aasoci.2019.99030

Received: July 25, 2019

Accepted: September 7, 2019

Published: September 10, 2019

Copyright $\odot 2019$ by author(s) and Scientific Research Publishing Inc. This work is licensed under the Creative Commons Attribution International License (CC BY 4.0).

http://creativecommons.org/licenses/by/4.0/

c) (i) Open Access

\begin{abstract}
The aim of this study deals with praxis communication mechanisms that are at the heart of motor playfulness interactions formed in the practice of volleyball. This research perspective offers the opportunity to better grasp and understand the motor behavior of players that are shaping a social motor skills network revolving around cooperative and adversarial. From there, it seemed interesting to study the content of practicing volleyball at both high-level and at school. The joint communication network of sport is built on the frame of observable motor behavior of practitioners. Results revealed that within high-level sports, motor interactions of players are based on praxis communication networks being richer within school and club volleyball, thus highlighting links of opposition and cooperation around diverse and under-privileged social motor skills roles. In this context, we are questioning whether the technocratic and traditional approach of Volleyball is preferred over the approach of motor semiotic based on the study of motor behavior of practitioners and the praxis communication.
\end{abstract}

\section{Keywords}

Volleyball, Motor Skills Semiotic, Praxis Communication, Motor Behavior, Didactic Game

\section{Introduction}

Volleyball is a programmed activity within the school curriculum. A discipline difficult to adapt to pupils attending school, it is the subject of particular pedagogical attitudes of physical education teachers. On one hand, difficulties arise 
from the attitude of rejection, because they are related to the techniques that should be mastered in order to create a real game between the players. On the other hand, teachers work to develop specific skills in learners where technical initiation and the acquisition of gestural skills are necessary, based on the sport model. Indeed, "team games are rejected... in favour of sports practices considered more serious or superior" (Dugas, 2005: p. 43). Sports are a highly publicized social reference practice where the cultural reference to high-level athletes bases the choice of physical education teachers. This reference to sport is not new. The recent education sessions focus more on motor education through sport. "The sportivization of the physical education" (During, 2005: p. 70) is striking. In the performance of his duties, the physical education teacher identifies the skills to be developed in his pupils. His choices of learning content reflect "underlying learning options" (Récopé \& Boda, 2008: p. 21), carried by his reflections, training and personal experiences. This problem raises the question of "curricular dynamics" that underlies "a curriculum in action" (Amade-Escot \& Brière-Guenoun, 2014: p. 2). The crumbling is obvious. There is no longer a single reality of physical education, but many who are subject to multiple interpretations by actors. This is due to the lack of unification of teaching methods, which remains under the influence of sports "technicism" (Parlebas, 1990: p. 90). This sports-based education is based mainly on the principles of sports training, governed by the official Tunisian instructions (1990) and accented by the physical education programs in the volleyball cycle (1997). The duel activity where the control of a power is balanced between two groups of protagonistis carried out in accordance with the internal logic of the game. Action becomes the work of organized decision-making behaviours, because to operate, it is necessary to cooperate (Piaget, 1966).

However, in this competitive context, "in which athletes seek victory, dominance of one over the other to win" (Dugas \& Collard, 2009: p. 9), motor communication is perpetuated on the playfield and is expressed in terms of an interaction-relationship designed by rational and motivated choices that respond to other communicational imperatives. In fact, the practitioner focuses on runs, movements, stops or postures which are signs that involve to interpreting their meaning and assign them a significant scope (Parlebas, 2009). Thus we are in the presence of a specific semiology of collective sports games where a framework of motor messages is encoded and decoded. This requires a continuous decryption process during the game. The essence of this new type of communication is not verbal but practical which is highlighted by the body system and motor signs emitted on the field by interacting players.

The player must "pre-act and anticipate the act in progress" (Parlebas, 2007: p. 50), through the process of encoding his own motor skills and decoding the motor skills of others. This "semiotic" activity (Parlebas, 1990: p. 151) determines the choice of the setter who aspires to succeed in his driving task and depends on his level of expertise (beginner or expert). The motor interaction expresses the relational aspect between the volleyball players and is structured around "sociomotor roles" (Parlebas, 1999: p. 312) to which we have assigned 
"sociomotor sub-roles" (Parlebas, 1999: p. 344). These sociomotor statutes related to operational forms are manifested in both offensive (spikes, serves, etc...) and defensive (passes, reception) strategies.

In this context, during professional volleyball matches, the player's motor-interaction relationships are based on praxis communications networks richer than those in school volleyball and club volleyball, highlighting opposition and cooperation relationships around varied and privileged sociomotor sub-roles. By contrast, in physical education, we suppose that motor interactions would show a weak organization during motor exchanges in both technical and tactical level. The effectiveness of physical education pupils is measured by their ability to solve problems during the confrontation, to lead the game continuously by keeping the ball. In light of these facts, we are questioning the type of volleyball games that are prescribed in schools in Tunisia. Is that all the educational relevance of a collective game whose interests lies in the subtlety and wealth of the praxis interactions?

\section{Methods}

This research focuses on the study of Praxis Communication and the cooperative and opposition relationships expressed in sociomotor sub-roles networks changes of volleyball players part of three contrasted populations during competitive confrontations.

\subsection{Population}

Our investigations involved three populations of male players from different practice-level when they were in motor confrontation [see Table 1].

Concerning the high-level volleyball team, we obtained the recorded matches from the Tunisian Volleyball Federation when the Tunisian team was competing against the Serbian national team during the London 2012 Olympic Games. The observed subjects are the players of the field during their confrontation throughout the whole match, i.e. the six titular players of the Tunisian team playing against the six players of the Serbian team.

At the volleyball club level within the school sports association, the group belongs to the region of Cap Bon ${ }^{1}$ in Tunisia. The team consists of players whose ages are between 14 and 16 years old and belongs to the "minimal" category. The national quarterfinals and semi-finals qualifying matches were filmed during the period from March to May 2013.

The third population consists of pupils who practice volleyball during school physical education sessions. Also located in the region of Cap Bon, the players are between 14 and 16 years old and belong to the same secondary school. Pupils are subject to a volleyball cycle lasting 12 sessions at maximum and rated 2 hours per session (24 hours per cycle).

"CapBon" region is located in the north-east of Tunisia. The particularities of this region lie in the anchoring of volleyball sport, where this activity is growing considerably and arouses the interest of the government through the improvement of their structures to maintain dynamism and aims to achieve a level of professional practice. 
Table 1. Studied population.

\begin{tabular}{|c|c|c|}
\hline Studied population & Characteristics & Number of matches/Duration \\
\hline $\begin{array}{l}\text { High level volleyball } \\
\text { (HL.VB) }\end{array}$ & $\begin{array}{c}\text { London Olympic games } 2012 \\
\text { Tunisia \# Serbia }\end{array}$ & $\begin{array}{l}\text { one match } \\
\text { Duration: } 154 \mathrm{~min}\end{array}$ \\
\hline $\begin{array}{c}\text { School sport association } \\
\text { (SSA.VB) }\end{array}$ & $\begin{array}{l}\text { School sport association } \\
\text { (SSA) in Cap Bon region }\end{array}$ & $\begin{array}{l}\text { Two matches } \\
\text { Duration: match (1) } 54: 44 \mathrm{~min} \\
\text { Duration: match (2): } 38: 05 \mathrm{~min}\end{array}$ \\
\hline $\begin{array}{l}\text { Volleyball of physical } \\
\text { education } \\
\text { (PE.VB) }\end{array}$ & $\begin{array}{l}\text { Physical education course in two } \\
\text { schools in Cap Bon }\end{array}$ & $\begin{array}{l}\text { Two matches during two physical } \\
\text { education sessions. } \\
\text { Duration: session (1) } 30: 05 \mathrm{~min} \\
\text { Duration: session (2) } 38: 18 \mathrm{~min}\end{array}$ \\
\hline
\end{tabular}

\subsection{Observation}

Five matches were monitored. The same recording device was applied to the school sports association volleyball group and the physical education volleyball group. A fixed recording camera was placed behind the end line at a height of more than three meters provided good visibility of the whole playground. A second mobile camera allowed the capturing of images of the main sequences of interactions that took place. The deferred observation has enabled to consign all the practical interactions and "the complex process of this exchange" (Pandraud, 2013: p. 9) between the volleyball players observed on-situ situations (Boudon, 1979): the subjects, the situation constraints, and the emerging effects. The monitoring of the change from one sociomotor sub-role to another which assigned to the player's status in the "ludo-sporting space" (Parlebas, 1986), has allowed a continuous coding activity (see Table 2).

Our procedure consists of consigning all motor interactions in an observation grid developed and inspired by Obøuf's work (2012: pp. 161-162). To ensure this, we followed the circulation of the ball, which expresses the passages from one sociomotor sub-role to another endorsed by the players, in the order of their appearance (refer to Figure 1).

These exchanges were recorded and classified into two categories: the cooperation (when the exchange occurs in intra-team) and the opposition (when the exchange is done in inter-team). Our grid has been more refined and has also included the qualitative aspect, expressing successful exchanges marked with the symbol $(+)$ and the failed exchanges that were identified by the symbol (-). The throwback into play marks the beginning of each sequence, which is defined by the start of a new service and ends when the ball lands in the opponent's court that leads a team to restart the game (see Table 3 ).

\section{Results}

\subsection{Analysis of the Praxis Interactions between Volleyball Players in Competitive Situations}

Built on a series of relationships that underlie praxis communication forms of cooperation and opposition, the player's motor interactions are highly dependent 


\section{Sociomotor sub-role (1)}

Sociomotor sub-role (2)

[Setter]

[Hitter]

Figure 1. Example of a coding exchange from a sociomotor sub-role to another.

Table 2. Volumetric of game observations played in the three volleyball populations.

\begin{tabular}{|c|c|c|}
\hline Population observed & Full time played & Time of observation \\
\hline $\begin{array}{l}\text { High level volleyball } \\
\text { (HL.VB) }\end{array}$ & $154 \mathrm{~min}$ & $\begin{array}{c}2310 \mathrm{~min} \\
\text { Equal to } 38 \text { h } 30 \mathrm{~min}\end{array}$ \\
\hline $\begin{array}{c}\text { School sport association } \\
\text { volleyball } \\
(\text { SSA.VB })\end{array}$ & $\begin{array}{l}54.44 \mathrm{~min} \\
38.05 \mathrm{~min}\end{array}$ & $\begin{array}{c}816.6 \mathrm{~min} . \\
\text { Equal to } 13 \mathrm{~h}, 36 \mathrm{~min}, 6 \mathrm{secs} \\
570.75 \mathrm{~min} . \\
\text { Equal to } 9 \mathrm{~h}, 30 \mathrm{~min}, 75 \mathrm{secs}\end{array}$ \\
\hline $\begin{array}{c}\text { Volleyball of physical } \\
\text { education } \\
\text { (PE.VB) }\end{array}$ & $\begin{array}{l}30.05 \mathrm{~min} \\
38.18 \mathrm{~min}\end{array}$ & $\begin{array}{c}450.75 \mathrm{~min} \\
\text { Equal to } 7 \mathrm{~h}, 30 \mathrm{~min}, 75 \text { secs } \\
572.7 \mathrm{~min} \\
\text { Equal to } 9 \mathrm{~h}, 32 \mathrm{~min}, 7 \mathrm{secs}\end{array}$ \\
\hline Total & $\begin{array}{c}314.72 \mathrm{~min} \\
\text { Equal to } 5 \mathrm{~h}, 14 \mathrm{~min}\end{array}$ & $\begin{array}{c}4720.8 \mathrm{~min} \\
\text { Equal to } 78 \mathrm{~h}, 40 \mathrm{~min}, 8 \text { secs }\end{array}$ \\
\hline
\end{tabular}

Table 3. Observation grid extracted from a volleyball game sequence of the school sports association.

\begin{tabular}{|c|c|c|c|c|c|c|c|}
\hline \multicolumn{3}{|c|}{ Qualitative observation } & $\begin{array}{l}\text { Quantitative } \\
\text { observation }\end{array}$ & \multicolumn{3}{|c|}{ Qualitative observation } & Quantitative \\
\hline \multicolumn{4}{|c|}{ Rapport de coopération (+) } & \multicolumn{4}{|c|}{ Rapport d'antagonisme (-) } \\
\hline $\begin{array}{l}\text { 4. Setter } \\
{[G]} \\
\text { Position } 6\end{array}$ & $\rightarrow$ & $\begin{array}{r}\text { Rec } \\
\text { Posi }\end{array}$ & $+/+$ & $\begin{array}{c}\text { st }^{r} \text { kick off of the game } \\
\text { 1. Server } \\
{[\mathrm{G}]} \\
\text { Position } 1\end{array}$ & $\rightarrow$ & $\begin{array}{l}\text { Receiver } \\
\text { [K] } \\
\text { Position } 1\end{array}$ & $+1-$ \\
\hline $\begin{array}{l}\text { 5. Setter } \\
{[G]} \\
\text { Position } 3\end{array}$ & $\rightarrow$ & $\begin{array}{r}\operatorname{Rec} \\
\text { Posi }\end{array}$ & $+/+$ & $\begin{array}{c}2^{\text {nd }} \text { kick off of the game } \\
\text { 2. Server } \\
{[G]} \\
\text { Position } 1\end{array}$ & $\rightarrow$ & $\begin{array}{l}\text { Receiver } \\
\quad[\mathrm{K}] \\
\text { Position } 6\end{array}$ & $-/+$ \\
\hline $\begin{array}{l}\text { 7. Setter } \\
{[\mathrm{K}]} \\
\text { Position } 4\end{array}$ & $\rightarrow$ & $\begin{array}{r}\operatorname{Rec} \\
\text { Posi }\end{array}$ & $+/+$ & $\begin{array}{c}3^{\text {rd }} \text { kick off of the game } \\
\text { 3. Server } \\
{[\mathrm{K}]} \\
\text { Position } 1\end{array}$ & $\rightarrow$ & $\begin{array}{l}\text { Receiver } \\
\text { [G] } \\
\text { Position } 6\end{array}$ & $-1+$ \\
\hline $\begin{array}{l}\text { 8. Setter } \\
{[\mathrm{K}]} \\
\text { Position } 3\end{array}$ & $\rightarrow$ & $\begin{array}{r}\operatorname{Rec} \\
\text { Posi }\end{array}$ & $+/+$ & $\begin{array}{c}\text { 6. Setter } \\
{[G]} \\
\text { Position } 2\end{array}$ & $\rightarrow$ & $\begin{array}{l}\text { Receiver } \\
\quad[\mathrm{K}] \\
\text { Position } 4\end{array}$ & $-1+$ \\
\hline & & & & $\begin{array}{c}\text { End of the sequence } \\
9 . \text { Hitter } \\
{[\mathrm{K}]} \\
\text { Position } 4\end{array}$ & $\rightarrow$ & $\begin{array}{l}\text { Receiver } \\
\quad[\mathrm{G}] \\
\text { Position } 5\end{array}$ & $+1-$ \\
\hline
\end{tabular}

on the level of practice and determine the value of one sociomotor sub-role over another that would lead to a victory through the interaction mark in favour of the team. 
The data in Table 4 allows us to have certain representativeness of what is being played and the most solicited sociomotor sub-roles in the three levels of practice. Invested differently by the three populations, the sociomotor sub-roles are endorsed by the players according to their level of practice and motor skills. The high-level volleyball players and the sports school association players show clearly a game based on opposition blocker (76.09\%), hitter (53.95\%), placer (77.63\%), lober (68.24\%), whereas the physical education pupils show a low rate of sociomotor sub-roles invested during the competition. The sociomotor sub-role of server $(33.33 \%)$ reflects the frequency of cumulative game strokes without succeeding the sociomotor exchanges. Overall, 1146 changes in sociomotor sub-roles were consigned in 100 relaunches into the game. These changes include the entire cooperative and the opposition passages studied in the three populations.

\subsection{Analysis of the Success Rates in Changes Operated in Cooperative Sociomotor Sub-Roles in the Three Populations}

The data in Table 5 below reveal that high-level volleyball players succeed with $100 \%$ the co-operative exchanges with a particular predominance of the change operated between the sociomotor sub-role of raiser and the setter (49.18\%) and between the sociomotor sub-role of the setter and the hitter (46.72\%). All the players cooperate to succeed through an offensive built strategy. However, the change from sociomotor sub-role of placer is not used by the high-level teams. This shows clearly that they prioritize the passage to the sociomotor sub-roles of setters to hitters, which reflect the preparation phase of the offensive act. This aspect is perceived through the solicitation of the main sociomotor sub-roles of raiser, who orient the first pass towards the setter, involving the sociomotor sub-role of hitter to build the further offensive construction.

The majority of the co-operative exchanges among the players in the school sports association (\%) in all the co-operative interaction relationships consigned show a high success rate (98.94\%) except for the exchanges operated between the sociomotor sub-roles of raiser to the setter $(1.5 \%)$ and the setter to the Placer

Table 4. Frequency of the socio-motor sub-roles solicited in each population.

\begin{tabular}{cccccccccc}
\hline \multicolumn{7}{c}{ Sociomotor sub-roles } \\
\hline & Setter & Raiser & Hitter & Server & Lober & Placer Receiver Blocker Total rows \\
\hline HL.VB & 120 & 124 & 116 & 100 & 6 & 14 & 174 & 35 & 689 \\
Frequency\% & $43.80 \%$ & $40.52 \%$ & $53.95 \%$ & $33.33 \%$ & $31.58 \%$ & $13.21 \%$ & $37.99 \%$ & $76.09 \%$ & $39.97 \%$ \\
SSA.VB & 135 & 150 & 99 & 100 & 13 & 82 & 217 & 11 & $\mathbf{8 0 7}$ \\
Frequency\% & $49.27 \%$ & $49.02 \%$ & $46.05 \%$ & $33.33 \%$ & $68.42 \%$ & $77.36 \%$ & $47.38 \%$ & $23.91 \%$ & $46.81 \%$ \\
PE.VB & 19 & 32 & 0 & 100 & 0 & 10 & 67 & 0 & 228 \\
Frequency\% & $6.93 \%$ & $10.46 \%$ & $0.00 \%$ & $33.33 \%$ & $0.00 \%$ & $9.43 \%$ & $14.63 \%$ & $0.00 \%$ & $13.23 \%$ \\
Total columns & 274 & 306 & 215 & 300 & 19 & 106 & 458 & 46 & 1724 \\
\hline
\end{tabular}


Table 5. Change in sociomotor sub-roles of cooperation in the three studied populations.

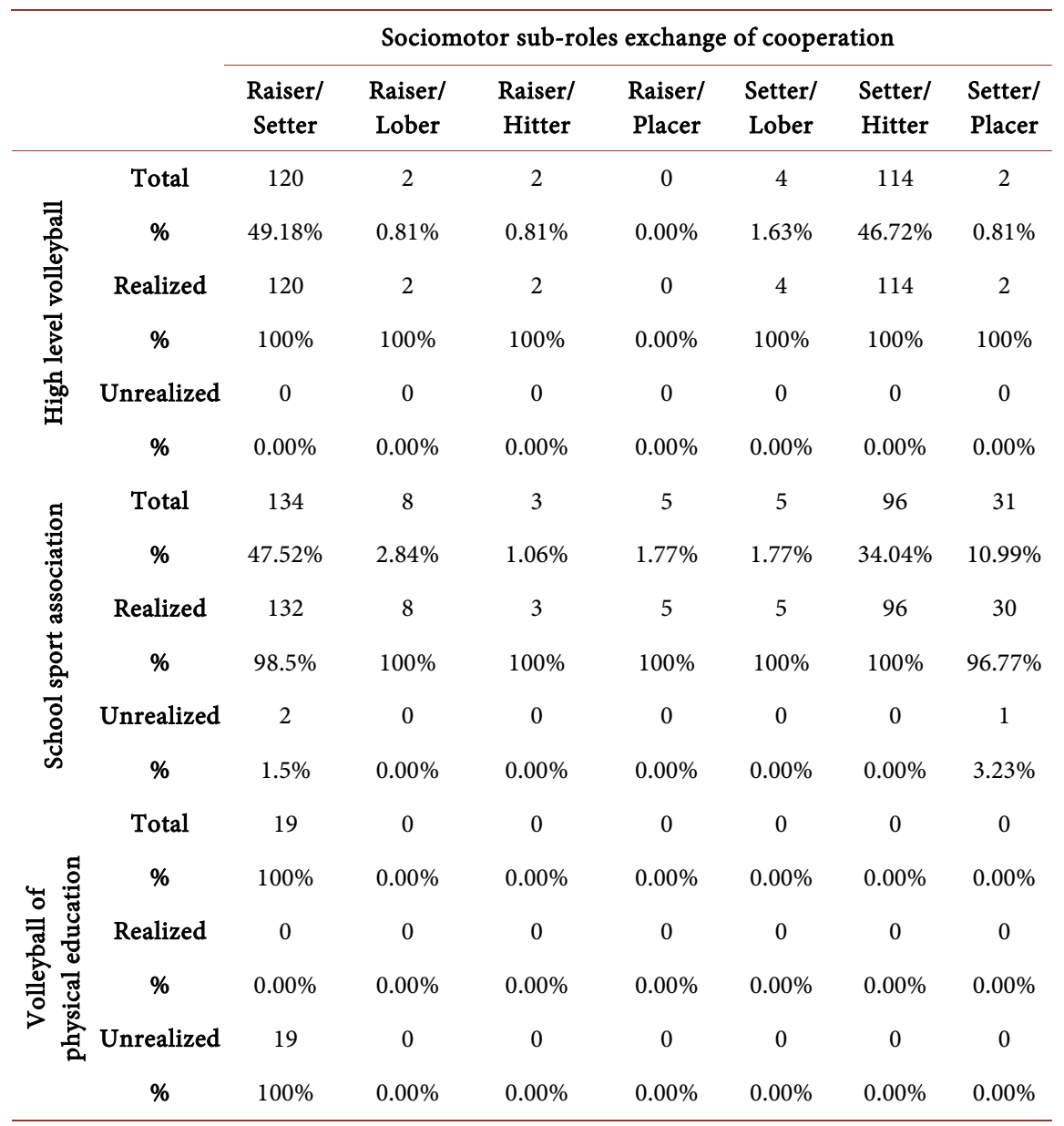

(3.23\%). Despite this low rate, the unsuccessful exchanges occur when the player is endorsing the sociomotor sub-role of Raiser and the player who performs the sociomotor sub-role of the Setter. As well as the player who is submitting the sociomotor sub-role of the Sstter and the player who assumes the sociomotor sub-role of the Placer. In addition to the player who endorsed the sociomotor sub-role of the setter and the player who assumes the sociomotor sub-role of the placer. This phase shows the difficulty related to the orientation of the first incoming ball from the opposing court and to the solicitation of the player who is taking on the sub-role of placer. This is perceived in orienting the ball received from the opposing side where the player tends to spike it instead of hitting it. However, these exceptional difficulties do not reflect a lack of cooperation relations, because we note that the other passages of the sociomotors sub-roles have been $100 \%$ successful.

However, concerning the pupils in physical education, we notice that the majority of sociomotor sub-roles exchanges were unsuccessful. Our data highlight an absence of these changes in all the identified sociomotor sub-roles, excepted for the interaction relationship between sociomotorsub-role of the raiser to the setter, where this sequence (perceived 19 times) was completely unsuccessful. 
Indeed, the results related to the unsuccessful interactions that are referred in changes in sociomotor sub-role occurr in the context of ball launch, as well as those involved in the transitions operated between the sociomotor sub-role of setter and the sociomotor sub-role of lober, hitter, and placer. Thus, we note that the pupils of the physical education are struggling to concretize the enchainment of the sociomotor sub-roles and to coordinate their motor actions to build an offensive strategy by orienting the second and the third touch of the ball. These difficulties highlight the weakness of the organization in the playing field. In particular, the raiser player's performance after receiving the ball from the opposite side to orient it towards the rivals. The observed low rate confirms this constraint associated with the execution of the motor task despite their multiple attempts.

\subsection{Analysis of the Success Rates in Changes Operated in Opposition Sociomotor Sub-Roles in the Three Populations}

Our data referring to Table 6 below shows that the Opposition exchanges in the sociomotor sub-roles of antagonism for the high-level volleyball players have at

Table 6. Change in the sociomotor sub-roles of volleyball antagonism in the three studied populations.

\begin{tabular}{|c|c|c|c|c|c|c|c|c|}
\hline & & \multicolumn{7}{|c|}{ Sociomotor sub-roles exchange of opposition } \\
\hline & & $\begin{array}{c}\text { Server/ } \\
\text { Raiser }\end{array}$ & $\begin{array}{l}\text { Hitter/ } \\
\text { Receiver }\end{array}$ & $\begin{array}{l}\text { Hitter/ } \\
\text { Blocker }\end{array}$ & $\begin{array}{l}\text { Lober/ } \\
\text { Receiver }\end{array}$ & $\begin{array}{l}\text { Lober/ } \\
\text { Blocker }\end{array}$ & $\begin{array}{l}\text { Placer/ } \\
\text { Receiver }\end{array}$ & $\begin{array}{l}\text { Placer/ } \\
\text { Blocker }\end{array}$ \\
\hline \multirow{6}{*}{ 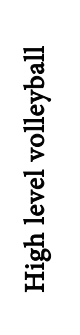 } & Total & 89 & 71 & 31 & 2 & 4 & 12 & 0 \\
\hline & $\%$ & $42.58 \%$ & $33.97 \%$ & $14.83 \%$ & $0.96 \%$ & $1.91 \%$ & $5.74 \%$ & $0.00 \%$ \\
\hline & Realized & 82 & 28 & 24 & 2 & 3 & 10 & 0 \\
\hline & $\%$ & $92.13 \%$ & $39.44 \%$ & $77.42 \%$ & $100 \%$ & $75 \%$ & $83.33 \%$ & $0.00 \%$ \\
\hline & Unrealized & 7 & 43 & 7 & 0 & 1 & 2 & 0 \\
\hline & $\%$ & $7.87 \%$ & $60.56 \%$ & $22.58 \%$ & $0.00 \%$ & $25 \%$ & $16.67 \%$ & $0.00 \%$ \\
\hline \multirow{6}{*}{ 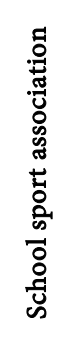 } & Total & 119 & 106 & 10 & 11 & 2 & 74 & 3 \\
\hline & $\%$ & $36.62 \%$ & $32.62 \%$ & $3.08 \%$ & $3.38 \%$ & $0.62 \%$ & $22.77 \%$ & $0.92 \%$ \\
\hline & Realized & 106 & 54 & 8 & 10 & 2 & 71 & 3 \\
\hline & $\%$ & $89.08 \%$ & $50.94 \%$ & $80 \%$ & $90.91 \%$ & $100 \%$ & $95.95 \%$ & $100 \%$ \\
\hline & Unrealized & 13 & 52 & 2 & 4 & 0 & 3 & 0 \\
\hline & $\%$ & $10.92 \%$ & $49.06 \%$ & $20 \%$ & $36.36 \%$ & $0.00 \%$ & $4.05 \%$ & $0.00 \%$ \\
\hline \multirow{6}{*}{ 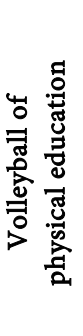 } & Total & 63 & 0 & 0 & 0 & 0 & 4 & 0 \\
\hline & $\%$ & $94.03 \%$ & $0.00 \%$ & $0.00 \%$ & $0.00 \%$ & $0.00 \%$ & $5.97 \%$ & $0.00 \%$ \\
\hline & Realized & 41 & 0 & 0 & 0 & 0 & 0 & 0 \\
\hline & $\%$ & $65.08 \%$ & $0.00 \%$ & $0.00 \%$ & $0.00 \%$ & $0.00 \%$ & $0.00 \%$ & $0.00 \%$ \\
\hline & Unrealized & 22 & 0 & 0 & 0 & 0 & 4 & 0 \\
\hline & $\%$ & $34.92 \%$ & $0.00 \%$ & $0.00 \%$ & $0.00 \%$ & $0.00 \%$ & $100 \%$ & $0.00 \%$ \\
\hline
\end{tabular}


the majority been achieved (71.29\%). The two changes in sociomotor sub-roles highlight the most significant offensive actions in the game phases: the start of the game by an offensive interaction that highlights the beginning of the exchange; and the mark interaction in favour of the team that reveals the rupture of the exchange. The change of the hitter's sociomotor sub-role towards the receiver sub-role and the server sub-role towards the receiver sub-role emphasizes a sustained interaction of opposition between the two teams. The balance of power oscillates between the opposing teams trying to counter their rivals' offensive strikes. This is perceived through the change of hitter sociomotor sub-role to the blocker sociomotor sub-role, where we note a considerable success rate $(77.42 \%)$. Practitioners prefer essentially a direct opposition relationship manifest in the act of striking the ball by involving the sociomotor sub-role of hitter. The blocker player's action consists of opposing or setting the ball.

Our data shows clearly that the offensive actions of the service and the spikeare the most privileged among the players in the school sports association group. This passage from the server sociomotor sub-role to the receiver is largely successful $(89.08 \%)$. During this phase, the beginning of the exchange is marked by the kick-off by the player performing the server sub-role, on which the opponent's motor behaviours are built. The successful enchainment of the sociomotor sub-roles thus reflects successful decoding of the server's action, which is reflected in the receiver's action. Besides, the preponderance of the sequence of the sociomotor sub-role from hitter to the receiver sub-role shows a shared rate of achievement (50.94\% success compared to $49.06 \%$ unrealized interactions).

These results indicate that the player's motor behaviors favor actions related to hitting and receiving the ball. The hitter's offensive action, produced by a quick and direct strike of the ball, is quickly received by the opposing team. Their motor behaviors are organized through an efficient placement to switch to cooperative conducts as part of an offensive construction phase. The transition from the placersociomotor sub-role to the receiver reveals a considerable frequency where the rate of achieved sociomotor sub-role change is equivalent to 95.95\%. This considerable achievement rate shows clearly that the players are trying to recover a poorly directed pass received from a partner by placing it on the opposing court.

Clearly, physical education pupils show little opposition interaction. Indeed, our results show a lower frequency of sociomotor sub-role combinations with a rate of $61.19 \%$. In these passages of antagonism sociomotor sub-roles, we only find that the changes from the server sub-role to the receiver (65.08\%) and from the placer sociomotor sub-role to the receiver sub-role were invested during interactions. The first phase of the sociomotor sub-role indicates the kick-off that marks the beginning of the game sequence and has been achieved by all the pupils. However, the rate of non-fulfillment (34.92\%) incurred by these practitioners refers to their difficulties at ball reception time and especially by the Receiver sociomotor sub-role. These players weren't able to decode the conduct of their opponents and effectively prevent the ball's strike path. Secondly, the sociomo- 
tor sub-role passage from the Placer to the Receiver shows unsuccessful connections. Basically, we consider that the pupils are trying to pass the ball to the opposing court instead of hitting it. According to these exchange difficulties, the players proceed with the direct return of the ball by placing it in the opposing camp. This reflects a determination to get rid of the ball due to the lack of their motor skills to build an offensive strategy. Counter-communications haven't been well established in the panel of antagonistic relationships and attests for the lack of motor skills perceived among pupils during motor competition.

The results of the three compared populations were established on three levels. First, we were able to identify the frequency of emergence of the socio-motor sub-roles solicited in each of the three observed population. This showed the predominance of the sociomotor sub-role of receiver, server, and raiser in all motor interactions. From this perspective, competition in volleyball is structured around two main phases: the beginning of the sequence ensured by the two sociomotor sub-roles the server and the receiver, and the offensive construction ensured by the exploitation of the raiser sub-role. These findings show perceived disparities, particularly among physical education. Pupils hardly operate these sociomotor sub-roles and we found a total absence of the hitter sociomotor sub-role, the lober, and the blocker sociomotor sub-role. In other words, only 4 of the 8 socio-motor sub-roles identified are used by the group of physical education during matches at a low rate, the server, the receiver, the placer, and the raiser. In contrast to the other two populations (the volleyball players of high level and the school sport association) these socio-motor sub-roles were all invested consubstantially.

Secondly, according to our results, we noticed the primacy of the sociomotor sub-role of the raiser to the setter during cooperative interactions in the studied populations. However, this sequence is not completed similarly. Clearly, the physical education group is different from the other two groups, and we noticed that the sequences performed within these two sociomotor sub-roles were not all carried out. During the antagonistic sequences, we were able to observe that the server/receiver pair is the most dominant in the three groups. However, a strong difference is perceived in this sequence. Once again, the physical education group stands out from the two other groups and shows a lower achievement rate (65.08\%, compared to $92.13 \%$ for high level players and $89.08 \%$ for school sport association players).

Finally, the communication networks during volleyball competitions in the high-level group are more rich and elaborated than those in the sports school association group or the physical education group. Although, the sports school association volleyball players, who have shown some unsuccessful exchanges, exploited $100 \%$ of the socio-motor sub-roles identified and succeeded in the socio-motor exchanges of cooperation and antagonism. However, the group of physical education reveals a low rate of sociomotor sub roles interactions. This reveals a weak organization of engine exchanges linked to both technical and tactical aspects. 


\section{Discussion}

The reality of the sport competition takes part in a complex communication process. The progress of the volleyball game is based on obvious interactions in the player's behaviours that are significant during exchanges taking place on the ground during matches. The motor actions of the practitioners require "continuous coordination with the behaviors of other players" Parlebas (2007: p. 50). Our results confirm the existence of a praxis semantics that illustrates "a network of interdependencies between players" (Parlebas, 1986: p. 237). Far from the idea of the "gesture endowed with autonomy" in Birdwhistell's theory of communicational interaction (1970), the communicational system appears as the fundamental fact during exchanges in sports duels.

In this interactional context, the volleyball player's motor action requires continuous coordination with the other co-actors. Under the game rules as a "powerful normative mediator" (Parlebas, 1986: p. 97), the players driving behavior's reveals a game tactic developed by each of the protagonists during the motor confrontations. The "internal logic" (Parlebas, 1999: p. 216) of volleyball define the system of relationships between players that vary from one level of practice to another. "Behavioural units" (Obœuf, 2010: p. 157) are successive in a precise order and articulated around privileged sociomotor sub-roles. The praxis deployed by professional volleyball players known as a "paradoxical communication" (Watzlawick et al., 1967: p. 136), highlight ambivalent relationships perceived in the rates of achievement of changes in the sociomotor sub-roles of cooperation (100\%) and antagonism (71.29\%). "These praxemic variables" (Obœuf, 2010: p. 91) are close to the level of practitioners of volleyball school association (cooperation ratio $98.94 \%$, and antagonism ratio $78.15 \%$ ), but are clearly differentiated from those of volleyball players in physical education (no cooperation was successful, against $61.19 \%$ of antagonism).

The "praxemic code" (Parlebas, 1990: p. 122) is quite different from Hall's (1971) "proxemic code" when it comes to a confirmed level of practice. The player is always on the hunt for "indices, based on his familiarity with the situation, his acquired experience, and habits" (Parlebas, 1999: p. 261). He must not therefore act, but must effectively anticipate the imminent driving action of the protagonists and "pre-act" (Parlebas, 1999: p. 272). This ability to make decisions and anticipate is the subject of a long-term motor adaptation during training sessions. For Metzler (1992: p. 52), volleyball is a duel in which two teams or two players continuously interact in a sequence and involves the process of encoding and decoding of "motor conducts"2 (Dugas, 2011: p. 16).

These processes further value the two most characteristic force ratios of vol-

${ }^{2}$ The individual acting in the context of physical and sporting activities cannot be reduced to a set of motor behaviours, nor a moving body expending energy. This distinction is highlighted in the introductory part of Duga's book, The Systemic Man (2011: p. 16), which emphasizes the central notion of motor skills, "complex to analyze, it carries meaning, and has an active meaning that is not directly perceptible, but involves both affectivity and rationality and refers to the cultural context". In this sense, the concept of "motor driving" refers to "the significant organization of motor behaviour" and thus reflects the motor action. 
leyball, expressing the rivalry and highlighted by Metzler (1992: p. 52): on one hand, the ratio of force "service-reception" where the opening of the game by a service with force leads to a greater probability of mistakes among opponents. On the other hand, after the reception, the players tend an oblique pass technique over the net (fast and close to the net), to put their opponents in time-crunch. Our results prove these facts, where we found a significant rate of achievement in the changes from antagonistic sociomotor sub-roles from server to receiver for high-level players and volleyball school association players (92.13\% and $89.08 \%$ respectively) compared to physical education pupils.

In light of this, we can no longer conceive the teaching of volleyball at schools based on gestuality and the duplication of purely technical motor responses issued from the sports model. Moreover, the time allocated to the practice of this activity ( 8 to 12 sessions per learning cycle) is not sufficient to foster successful praxis exchanges among pupils.

They are no longer subject to years of intensive practice to achieve such results. However, if we would practice this activity without denaturing it, it is imperative to use a new approach in order to take the pupils out of the circle of eternal beginners and lead them to a successful game by setting and receiving the ball because relationships between the practitioners, "cements all sports or school learning" (Dugas \& Bordes, 2008: p. 65).

In light of this, we can no longer conceive the teaching of volleyball at schools based on gestuality and the duplication of purely technical motor responses issued from the sports model. Moreover, the time allocated to the practice of this activity ( 8 to 12 sessions per learning cycle) is not sufficient to foster successful praxis exchanges among pupils. They are no longer subject to years of intensive practice to achieve such results. However, if we would practice this activity without denaturing it, it is imperative to use o a new approach in order to take the pupils out of the circle of eternal beginners and lead them to a successful game by setting and receiving the ball because relationships between the practitioners, "cement all sports or school learning" (Dugas \& Bordes, 2008: p. 65).

In this perspective, school volleyball can be considered according to a learning approach based on didactic sports games that relate "a set of motor situations codified by teachers according to educational standards and for pedagogical purposes" Dugas (2004: p. 14). The aim is to transform this sport by taking into account the educational characteristics of learners and to enhance the operational interactions built around networks of cooperation and opposition exchanges. Therefore, it is important to base learning on a semiotic approach that allows us to work directly on cooperation with partners and opposition with adversaries by teaching them better communication. These processes lead to a "logic of schooling" of the practice of volleyball towards a new category of sports games created by Éric Dugas (2004): "didactic games" so that this activity becomes "a reference situation and not the only reference" (Bordes, Collard, \& Dugas, 2007: p. 115). 


\section{Conclusion}

This study highlighted the richness and complexity of practical communication in three contrasting volleyball practice contexts. The interaction modalities were revealed through the analysis of the players' motor interactions according to their behaviour during competitions. The emotional, social and cognitive aspects have a significant influence on intra-team and inter-team relationships and are expressed through antagonism or solidarity. The praxis communication depends here, in a considerable way, on the level of practice of the players. It is based on communication and counter-communication and shows the ability of the participants to perceive the motor signs of their partners/opponents to react effectively during the game. However, this interpretation of the conduct of others, their decisions and anticipations are part of a set of rules that affect several aspects of sports training. The potentialities of practitioners who tend to a level of excellence can, therefore, be learned, according to a type of training that is not only technical or physical but also semiotic, especially when it is a beginner in physical and sports education classes. Our goal is to implement training content based on the development of collective motor skills based on "an operating logic" as recommended in the studies conducted by Delaunay (1985). This method of learning motor strategies would be more effective than "technicist" approach sports training. A player's effectiveness can no longer be associated solely with the learning of technical, tactical or physical skills, but is also based systemically on semiotic learning of motor behaviours that is established within motor exchange networks (Collard, 2002).

\section{Conflicts of Interest}

The authors declare no conflicts of interest regarding the publication of this paper.

\section{References}

Amade-Ecsot, C., \& Brière-Guenoun, F. (2014). Questionner le curriculum en éducation physique et sportive: Quelledynamique en contexte? Quelle autonomie? Questions vives. http://questionsvives.revues.org/1683

Birdwhistell, R.-L. (1970). Kinesics and Context: Essays on Body Motion and Communication. Philadelphie, PA: University of Pennsylvania Press. https://doi.org/10.9783/9780812201284

Bordes, P., Collard, L., \& Dugas, É. (2007). Vers une science des activités physiques et sportives. La science de l'action motrice. Paris: Vuibert.

Boudon, R. (1979). La logique du social: Introduction à l’analyse sociologique. Paris: Hachette.

Collard, L. (2002). Aplicaciones de la nocion de conducta motriz en el entrenamiento deportivo (Application de la notion de conduite motrice en entrainement sportif). In Proceedings of 7th International Seminar on Motor Praxeology (pp. 136-151). Lleida, INEFC.

Delaunay, M. (1985). Des transactions sociomotrices à la pédagogie sémio-opératoire. In 
M. Laurent, \& P. Therme (Eds.), Recherches en activités sportives 1 (pp. 45-59). Marseille: Centre de recherche de l'U.E.R.E.P.S Aix-Marseille II.

Dugas, É. (2004). Des pratiques sociales aux pratiques scolaires en EPS: Des logiques de scolarisation plurielles. Revue Française de Pédagogie, 149, 5-17. https://doi.org/10.3406/rfp.2004.3168

Dugas, É. (2005). Jeux collectifs, les enseignants privilégient le sport. Revue éducation physique et sport, 312, 42.

Dugas, É. (2011). L’homme systémique. Pour comprendre les pratiquants des jeux sportifs. Nancy: Presses Universitaires de Nancy.

Dugas, É., \& Bordes, P. (2008). Le volleyball serait-il le Pluton de notre système scolaire? Revue éducation physique et sport, 330, 62-66.

Dugas, É., \& Collard, L. (2009). Les sportifs et les interactions stratégiques sous l'angle de la théorie des jeux expérimentale. Presses universitaires de Liège, Les cahiers internationaux de Psychologie sociale, 81, 7-24. https://doi.org/10.3917/cips.081.0007

During, B. (2005). L'éducation physique, une discipline en progrès? Carrefours de l'éducation, 20, 61-87. https://doi.org/10.3917/cdle.020.0061

Hall, E.-T. (1971). La dimension cachée. Paris: Seuil.

Metzler, J. (1992). Volleyball, histoire des techniques: Conséquences didactiques. Revue éducation physique et sport, 234, 50-54.

Obœuf, A. (2010). Sport, communication et socialisation. Paris: Editions des archives contemporaines.

Obœuf, A. (2012). Sport et socialisation. In P. Parlebas, \& L. Collard (Eds.), Sport et bien être relationnel (pp. 149-170). Paris: Chiron.

Pandraud, N. (2013). Unethéorie de l'observation in Situ. http://sociologies.revues.org/4315

Parlebas, P. (1986). Eléments de sociologie du sport. Paris: Presses universitaires de France.

Parlebas, P. (1990). Activités physiques et éducationmotrice. Revue éducation physique et sport, 90, 122-123, 150-151.

Parlebas, P. (1999). Jeux Sports et Sociétés. Lexique de praxéologiemotrice. Paris: Institut national du sport, de l'expertise et de la performance. https://doi.org/10.4000/books.insep.1067

Parlebas, P. (2007). Pertinence motrice et complexité dans les jeux et les sports. In Les actes de lecture (No. 98, pp. 49-65). Paris: Revue éducation physique et Sport.

Parlebas, P. (2009). Un champ du signe discordant: La sémiotricité. Revue Ethologie et praxéologie, 13, 5 .

Piaget, J. (1966). La psychologie de l'enfant. Paris: Presses Universitaires de France.

Récopé, M., \& Borda, B. (2008). Raisons d'agir, raisons d’apprendre. Dossier éducation physique et sport, 76, 18.

Watzlawick, P., Beavin, J.-H., \& Jackson, D.-D. (1967). Une logique de la communication (Moche, J., Trad.). Paris: Seuil. 